\title{
Critical evaluation of the safety of Cimicifuga racemosa in menopause symptom relief
}

Tieraona Low Dog, MD, ${ }^{1}$ Kara L. Powell, MBA, ${ }^{2}$ and Steven M. Weisman, $\mathrm{PhD}^{2}$

\begin{abstract}
Objective: This comprehensive review examines the safety of Cimicifuga racemosa for the treatment of menopause symptoms, particularly in populations in which conventional menopause treatment regimens, including estrogen replacement, are contraindicated.

Design: An extensive database of information on Cimicifuga, which included all published literature pertaining to preclinical and clinical safety of various forms of Cimicifuga, the FDA and World Health Organization adverse-event reporting systems, monographs, compendia, internal unpublished data from a major manufacturer, foreign literature, and historical anecdotal reports, was reviewed, and findings pertaining to the safety of Cimicifuga use for menopause treatment were reported.

Results: Uncontrolled reports, postmarketing surveillance, and human clinical trials of more than 2,800 patients demonstrate a low incidence of adverse events (5.4\%). Of the reported adverse events, $97 \%$ were minor and did not result in discontinuation of therapy, and the only severe events were not attributed to Cimicifuga treatment.

Conclusions: Although the effects of Cimicifuga may be dependent on the specific extract preparation, this review clearly supports the safety of specific Cimicifuga extracts, particularly isopropanolic preparations, for use in women experiencing menopausal symptoms and as a safe alternative for women in whom estrogen therapy is contraindicated.
\end{abstract}

Key Words: Black cohosh - Cimicifuga racemosa - Menopause - Safety - Toxicology.

$\mathrm{M}$ enopause, a naturally occurring phenomenon in women between the ages of 40 and 60 years, represents the cessation of menstrual cycles and corresponding loss of estrogen and progesterone secretion. A significant number of women entering menopause exhibit symptoms - including hot flashes, night sweats, irritability, depression, anxiety, and sleep disorders - that can lead to significant disruptions in the course of daily life. In extreme cases, such symptoms lead women to seek medical attention.

Hormone replacement therapy (HRT), a commonly prescribed treatment for managing the long-term ef-

Received October 5, 2002; revised and accepted December 23, 2002.

From ${ }^{1}$ Integrative Medicine Education Associates, Corrales, NM, and ${ }^{2}$ Innovative Science Solutions, LLC, Morristown, NJ.

Address reprint requests to Steven M. Weisman, PhD, 67 Park Place East, Morristown, NJ 07960. Address correspondence requests to Tieraona Low Dog, MD, 353 Loma Larga NW, Corrales, NM 87048; e-mail: lowdogmd@aol.com. fects of lowered estrogen and progestogen levels, is often recommended for relieving distressing menopausal symptoms. Although estrogen therapy has beneficial effects on bone health and osteoporosis ${ }^{1}$ and has been used successfully for decades to treat the estrogen deficiency symptoms of menopause, known side effects associated with HRT include bloating, breast tenderness, cramping, irritability, depression, breakthrough bleeding, or a return to monthly periods. Other potential side effects of HRT, which cause many women to seek alternatives, include increased risk of endometrial, ovarian, and breast cancers ${ }^{2,3}$ from hormone-induced, estrogen receptor-positive cell proliferation. ${ }^{4}$ Risk of cancer associated with HRT is particularly high in women over the age of 55 years and in those who have used HRT for more than 5 years. ${ }^{3,5}$ On the basis of this risk and findings from the Women's Health Initiative, the US Preventive Services Task Force published a recommendation against the routine use of HRT for the prevention of chronic conditions in postmenopausal 
women. ${ }^{6}$ Therefore, women with, or at high risk for, estrogen-sensitive cancers are increasingly seeking safe and effective alternative therapies for the treatment of menopausal symptoms. Coupled with recent findings that HRT may not provide cardiovascular benefits as previously indicated, ${ }^{7}$ the risks associated with HRT have led many women to question whether such therapy is right for them.

Although a number of dietary supplements are available for the treatment of menopausal symptoms, including dong quai, evening primrose, ginseng, licorice, chasteberry, St. John's wort, red clover, vitamin E, and black cohosh, ${ }^{8}$ many people have concerns regarding safety, purity, and quality of such substances. ${ }^{9}$ Of these alternative therapies, the rhizome of black cohosh (Cimicifuga racemosa (L.) Nutt.), which has a long tradition of use for various clinical indications, is the most widely studied herb in menopause treatment. ${ }^{10} \mathrm{It}$ should be noted that other "alternative" treatments for menopausal symptoms are available by prescription, including clonidine and selective serotonin reuptake inhibitors.

C. racemosa, native to eastern North America and found from Georgia north to Ontario and west to Arkansas and Wisconsin, is an erect perennial that grows in forests. ${ }^{11}$ The leafy stalks and floret sprout from a rhizome, the organ from which commercially available extracts are derived. Black cohosh, a member of the buttercup family (Ranunculaceae), was first classified by Linnaeus as Actaea racemosa and later reclassified as Cimicifuga by Pursh. It was temporarily placed under the genus Macrotys, which led many eclectic practitioners to use macrotys as the common name of trade. However, the herb has been referred to by numerous names throughout history, including Actaea racemosa, Cimicifuga serpentaria, ${ }^{12-14}$ Botrophys racemosa, ${ }^{15}$ black cohosh, ${ }^{13,14}$ C. racemosa, ${ }^{13}$ Macrotys racemosa,${ }^{15,16}$ macrotys,,${ }^{17}$ black snakeroot,${ }^{12,14}$ and $\mathrm{C}$. racemosa (L) Nuttall. ${ }^{18}$ Squaw root, another term used to refer to black cohosh (Cimicifuga), has also been used to refer to blue cohosh (Caulophyllum thalictroides), an herb with a similar name ${ }^{15,19}$ but with a very different and distinct therapeutic profile. ${ }^{20}$ The use of ambiguous terminology in early literature reports highlight the need for caution when comparing reports of medicinal herbs. Geographic variations in plant species may also create confusion between actual species and terminologies of medicinal plants.

Native Americans have long recognized the beneficial effects of Cimicifuga, using the herb for the treatment of general malaise, kidney aliments, malaria, rheumatism, sore throat, and menstrual cramps and for ease of labor. US colonists also used the herb for treatment of amenorrhea, bronchitis, chorea, dropsy, fever, hysteria, itch, lumbago, nervous disorders, snakebite, yellow fever, and uterine disorders. ${ }^{21}$ Literature reports of Cimicifuga use date back as early as 1801, when eclectic physicians reported the use of Cimicifuga for relief of pain associated with acute rheumatism, neuralgia, ${ }^{16,18}$ influenza, smallpox, ${ }^{18}$ labor and postpartum pains, ${ }^{17}$ headache and cough, ${ }^{18}$ and chorea ${ }^{12}$ and other nervous system disorders ${ }^{22}$ as well as to encourage natural intermittent uterine contractions during labor. ${ }^{18,23}$

Although early reports indicate the effectiveness of Cimicifuga for a variety of indications, Cimicifuga extracts are used today primarily for the treatment of menopausal symptoms. Clinical evaluations ${ }^{24-31}$ support early reports suggestive of Cimicifuga use for relief of menopausal complaints. ${ }^{32}$

Since its introduction as a medicinal agent, clinical effects of Cimicifuga have been noted in various preparations, including rhizome powders, tinctures, infusions, and fluid or solid extracts. ${ }^{33}$ Early reports suggest Cimicifuga efficacy is dependent upon the type of formulation, ${ }^{13,18,22,34}$ with tinctures or extracts of the rhizome made with alcohol exhibiting greater effect than aqueous preparations and infusions. ${ }^{13,33}$

Today, a variety of Cimicifuga preparations, including isopropanolic and ethanolic extracts, are widely available. The proprietary isopropanolic preparation of Cimicifuga, Remifemin (developed and produced by Schaper \& Brümmer, Salzgitter, Germany, and marketed in the United States by GlaxoSmithKline Consumer Healthcare, Pittsburgh, PA) has been widely studied, thus providing supportive evidence for the safety of Cimicifuga extracts in menopause treatment. On the basis of clinical experiences with commercial products, the currently recommended dose of Cimicifuga is a $40 \%$ to $60 \%$ ethanol or isopropanol extract in a daily dose of 40 to $80 \mathrm{mg}$ herbal drug that is quality controlled for quantity of triterpene glycosides. ${ }^{35} \mathrm{~A}$ recently published study ${ }^{31}$ demonstrated that there is no superiority of a high dose of Cimicifuga $(127 \mathrm{mg} /$ day $)$ over the currently recognized $40 \mathrm{mg}$ /day dose, thus supporting the current recommended extract dose. Despite these findings, many have advocated the use of a higher daily dose $(80 \mathrm{mg})$ on the basis of the safety profile of Cimicifuga.

As both the indications for use and methods for preparation have changed since early reports of Cimicifuga use, it is important to distinguish the safety and efficacy findings of modern Cimicifuga extracts from reports on earlier extracts. This safety review specifi- 
cally addresses the safety of Cimicifuga use in the general menopausal population, as well as in specific patient groups. To address concern regarding the safety risks of Cimicifuga as an alternative to HRT, we emphasize studies investigating the estrogenic activity of the medicinal herb on estrogen levels and in estrogensensitive populations, including patients at risk for breast cancer.

\section{METHODS}

As is customary when evaluating safety data, we have considered all types of evidence including uncontrolled reports, postmarketing surveillance, preclinical studies, and controlled clinical evaluations (published and unpublished) to assess the safety of Cimicifuga therapy in women with menopausal complaints. Literature was identified through a search of MEDLINE, BIOSIS, EMBASE, and SciSearch for all published literature pertaining to preclinical and clinical safety of various forms of Cimicifuga. In addition, we reviewed the Food and Drug Administration (FDA) and World Health Organization (WHO) adverse-event reporting systems, monographs, compendia, internal unpublished data from Schaper \& Brümmer, and foreign literature, as well as collected historical, anecdotal reports. Further, we conducted tree-searching to identify other relevant articles. All articles identified were reviewed in an effort to conduct a comprehensive safety assessment.

Although we consider historical anecdotal reports of the safety of black cohosh, our analyses rely more heavily on more recent data generated with the commercially available Cimicifuga extracts.

\section{RESULTS}

\section{Historical reports on safety}

Until the late 1800s, the safety of various Cimicifuga preparations was determined through experience. The side effect profiles widely cited today for Cimicifuga are largely based on early reports with large doses of the crude herb and, therefore, lack relevance to currently marketed formulations. Original doses ranged from between 1 and 60 grains, corresponding to approximate doses of $65 \mathrm{mg}$ to $4.0 \mathrm{~g}$ crude herb, taken several times a day. ${ }^{12,13,18,22}$ Today, the recognized dose is $40 \mathrm{mg}$ of Cimicifuga extract per day; ${ }^{35}$ however, Cimicifuga capsules, tinctures and fluid extracts are readily available on the market that provide doses of up to $500 \mathrm{mg}$, or more, of crude herb. Early reports have reported that unspecified large doses of Cimicifuga, presumably those larger than the traditionally prepared doses of between 1 and 60 grains, may cause transient effects, including dizziness, ${ }^{36}$ vertigo, dimness of vision, and a depression of the pulse. ${ }^{13,37}$ Other early reports of macrotys suggest that large doses of the herbal preparation [apparently, more than 2 teaspoons (10 $\mathrm{mL}$ ) of tincture (unspecified concentration) every 3 hours] are associated with exhaustion and sickness of the stomach. ${ }^{38}$ Large doses of Cimicifuga in pregnant women are reported to induce abortion. ${ }^{37,39}$ Despite this reported reaction to unspecified large doses, early reports suggest that Cimicifuga exerts only weak "oxytoxic" (uterine stimulant) effect. ${ }^{39}$ However, further research is warranted to determine the safety of current black cohosh preparations during pregnancy.

Clinical effects of Cimicifuga for treatment of persistent neuralgia have been noted to be most beneficial after Cimicifuga doses large enough to induce a "full feeling" in the head accompanied by a dull headache. ${ }^{38}$ Whereas a headache could be considered an adverse reaction, it appears that early physicians considered this event a sign of clinical efficacy.

Animal studies evaluating the safety of Cimicifuga were introduced in 1887, with whole-animal investigations of the effects of Cimicifuga on frogs, rabbits, and dogs at extract concentrations of approximately 1.875 , 5.625 , and $10 \mathrm{~mL}$, respectively. ${ }^{40}$ These early in vivo studies confirm the findings of Davis, ${ }^{13}$ suggesting that Cimicifuga exerts a sedative effect, likely through the central nervous system. ${ }^{36}$

In 1932, Macht and Cook performed an experimental investigation of the fluid extract of Cimicifuga and of the isolated constituent, cimicifugin, to determine the effects of these preparations on various body functions. ${ }^{41}$ In contradiction to earlier animal data and use experiences, Macht and Cook's experiments suggest that Cimicifuga exerts very little sedative effect on the brain and neuromuscular functions of rats. Macht and Cook also noted adverse effects of the Cimicifuga preparation, including a relaxing and paralyzing effect on intestinal and uterine muscles, indicating a depressant and toxic property of the drug. Additionally, Macht and Cook noted a marked depression of respiration and circulation after intravenous administration of Cimicifuga, the latter of which confirms earlier observations of Cimicifuga. ${ }^{13,40}$ These ex vivo and animal studies provide some of the earliest scientific research available on Cimicifuga; however, the adverse effects noted by Macht and Cook are of limited relevance for oral human consumption at the doses typically used today.

Adverse events associated with Cimicifuga that are relevant to human use may be dependent on the specific 
TABLE 1. Adverse events to Cimicifuga as reported to the US Food and Drug Administration

\begin{tabular}{|c|c|c|c|}
\hline Adverse events as reported & Name of product & Manufacturer & Ingredients \\
\hline Heart attack & The Edge & $\begin{array}{l}\text { Adonis Health Products } \\
\text { (Lawrence, KS) }\end{array}$ & $\begin{array}{l}\text { Ma-huang, saw palmetto, wild yam, guarana, fo-ti, } \\
\text { skullcap, black cohosh, licorice root, royal jelly, bee } \\
\text { pollen, L-tryptophan, chromium, glandulars, amino } \\
\text { acids, lipotropics, sterols, calcium, magnesium, } \\
\text { octacosanol, RNA, DNA, others }\end{array}$ \\
\hline $\begin{array}{l}\text { Flushing of skin, swelling } \\
\text { of extremities and face, } \\
\text { headache }\end{array}$ & $\begin{array}{l}\text { Jenasol Circulation } \\
\text { Plus }\end{array}$ & $\begin{array}{l}\text { Jenasol, Inc } \\
\quad \text { (Hallandale, FL) }\end{array}$ & $\begin{array}{l}\text { Ginkgo biloba extract, butcher's broom, cayenne pepper, } \\
\text { ginger root, niacin, goldenseal, black cohosh }\end{array}$ \\
\hline $\begin{array}{l}\text { Pregnant female with } \\
\text { platelet count } 55,000, \\
\text { bleeding time of } 15 \mathrm{~min}, \\
\text { and hemoglobin of } 8.2\end{array}$ & $5-W$ & $\begin{array}{l}\text { Nature's Sunshine Products } \\
\quad \text { (Provo, UT) }\end{array}$ & $\begin{array}{l}\text { Black cohosh, squawvine, dong-quai, butcher's broom, } \\
\text { red raspberry leaf }\end{array}$ \\
\hline $\begin{array}{l}\text { Increasing anxiety, anger, } \\
\text { and stress }\end{array}$ & Eight Combination & $\begin{array}{l}\text { Nature's Sunshine Products } \\
\quad \text { (Provo, UT) }\end{array}$ & $\begin{array}{l}\text { Willow bark, black cohosh root, capsicum, valerian root, } \\
\text { ginger root, hops flowers, wood betony, devil's } \\
\text { claw root }\end{array}$ \\
\hline $\begin{array}{l}\text { Headaches, blurred vision, } \\
\text { lightheaded, dizziness }\end{array}$ & $\begin{array}{l}\text { Nature's Secret AM/PM } \\
\text { Ultimate Cleanse with } \\
\text { Multi-Fiber and } \\
\text { Multi-Herb }\end{array}$ & $\begin{array}{l}\text { Nature's Secret/4Health, } \\
\text { Inc (Los Angeles, CA) }\end{array}$ & $\begin{array}{l}\text { Hawthorn berry, red clover, skullcap, black cohosh, } \\
\text { slippery elm, echinacea, ginkgo biloba, cascara } \\
\text { sagrada, shattered cell wall chlorella, lactobacilli, } \\
\text { fenugreek, yarrow, horsetail, others }\end{array}$ \\
\hline $\begin{array}{l}\text { Diarrhea, progressive } \\
\text { proximal muscle } \\
\text { weakness, nephrotic } \\
\text { syndrome }\end{array}$ & $\begin{array}{l}\text { Internal Cleansing } \\
\text { System Multi-Herb } \\
\text { Formula }\end{array}$ & $\begin{array}{l}\text { Harmony Formulas, } \\
\text { Omni Nutraceuticals } \\
\text { (Los Angeles, CA) }\end{array}$ & $\begin{array}{l}\text { Fenugreek, yarrow flower, cat's claw, hawthorn berry, } \\
\text { Australian herb, licorice root, marshmallow, red } \\
\text { clover, red raspberry root, skullcap, burdock root, } \\
\text { chickweed, mullein, black cohosh, Irish moss, kelp, } \\
\text { slippery elm bark, echinacea, ginkgo, others }\end{array}$ \\
\hline $\begin{array}{l}\text { Severe chest pain, } \\
\text { "high" serum digoxin } \\
\text { level }\end{array}$ & Nature's Way Ex-Stress & $\begin{array}{l}\text { Nature's Way Products, Inc } \\
\text { (Springville, UT) }\end{array}$ & $\begin{array}{l}\text { Skullcap, wood betony, black cohosh, hops, valerian, } \\
\text { cayenne }\end{array}$ \\
\hline "Exhausted all the time" & $\begin{array}{l}\text { Unspecified BioSlim } \\
\text { product } \# 2\end{array}$ & $\begin{array}{l}\text { Medicus Formulas, Inc } \\
\text { (Woodland Hills, CA) }\end{array}$ & $\begin{array}{l}\text { Vitamin C, vitamin B6, coenzyme Q10, glucomannan, } \\
\text { chormium nicotinate, atractylodes, astragalus, } \\
\text { bupleurum, angelica sinensis, glycyrrhiza uralensis, } \\
\text { citrus peel, Cimicifuga, jujube, panax ginseng, } \\
\text { sargassum, laminaria, scutellaria, others }\end{array}$ \\
\hline $\begin{array}{l}\text { Headaches and high } \\
\text { blood pressure }\end{array}$ & Black cohosh tablets & $\begin{array}{l}\text { Enzymatic Therapy, Inc } \\
\text { (Green Bay, WI) }\end{array}$ & Black cohosh \\
\hline
\end{tabular}

herbal preparation. The freshness of the plant, for example, has been implicated as a factor determining the estrogen-like effects of Cimicifuga, as noted by von Gizycki. ${ }^{16,33,42,43}$ Because of the variety of indications and preparations, early reports of adverse events may not accurately reflect the current safety profile of Cimicifuga for treatment of menopausal symptoms.

\section{Uncontrolled reports}

In the United States, the FDA maintains the Special Nutrition Adverse Events Monitoring System (SN/AEMS), a database of adverse events reported voluntarily by consumers and healthcare professionals. Although the database may be suggestive of adverse events noted during postmarketing surveillance of a product, the database is not an accurate measure of all adverse events, and there is no certainty that a reported adverse event can be attributed to a particular product or ingredient. A search of the SN/AEMS database for adverse reactions to Cimicifuga (using search terms Cimicifuga and black cohosh) revealed nine adverse events reported on or before October 20,1998 44,45 (Table 1). Only one of the nine events (headaches and high blood pressure) was reportedly due to Cimicifuga as a solo agent (black cohosh tablets, Enzymatic Therapy Inc, Green Bay, WI). Other reported events were reported as a result of combination herbal therapies that included Cimicifuga. Because of the nature of such reporting, however, it is impossible to evaluate and verify actual exposure.

The WHO Collaborating Center for International Drug Monitoring also maintains a comprehensive database of adverse reactions reported worldwide. The WHO Collaborating Center receives summary clinical reports, with limited medical detail, that highlight indi- 
TABLE 2. Adverse events by organ system reported to World Health Organization Collaborating Center for International Drug Monitoring, July 2000

\begin{tabular}{|c|c|}
\hline Organ system & $\begin{array}{c}\text { Number of adverse } \\
\text { event reports }\end{array}$ \\
\hline Abdominal pain ${ }^{a}$ & 1 \\
\hline Arthralgia & 1 \\
\hline Back pain & 1 \\
\hline Breast enlargement $^{a}$ & 1 \\
\hline Breast pain $(\text { female })^{a}$ & 1 \\
\hline Depression & 1 \\
\hline Dermatitis & 1 \\
\hline Endometiral hyperplasia & 2 \\
\hline Epistaxis & 1 \\
\hline Fertility decreased (female) & 1 \\
\hline Genital neoplasm malignant & 1 \\
\hline Hemorrhage rectum & 1 \\
\hline Hepatic enzymes increased & 1 \\
\hline Hepatic failure & 1 \\
\hline Hepatitis & 1 \\
\hline Hypertension & 1 \\
\hline Hypertonia & 1 \\
\hline Intermenstrual bleeding & 1 \\
\hline Jaundice & 1 \\
\hline Malaise & 1 \\
\hline Menstrual disorder & 2 \\
\hline Nausea $^{a}$ & 1 \\
\hline Nephritis interstitial & 1 \\
\hline Pruritus & 1 \\
\hline Purpura & 1 \\
\hline Purpura thrombopenic throm & 1 \\
\hline Rash & 1 \\
\hline Rash erythematous & 2 \\
\hline Synovitis & 1 \\
\hline Thrombosis venous arm & 1 \\
\hline Urticaria & 1 \\
\hline Vaginal hemorrhage & 1 \\
\hline Total & 35 \\
\hline
\end{tabular}

${ }^{a}$ Symptoms of the corresponding gynecological syndromes such as premenstrual syndrome, dysmenorrhea, and menopausal complaints, all of which are indications of Cimicifuga use according to the German Commission E monograph.

vidual suspected adverse reactions to pharmaceutical products. A search of this database for all reported adverse reactions for Cimicifuga, including all salts/esters and Cimicifuga root, as of July 31, 2000, revealed a total of 35 adverse reactions. ${ }^{46}$ The reported reactions were primarily general symptoms and were not concentrated on a particular organ system (Table 2). Although it is impossible to accurately determine the actual exposure to Cimicifuga in these cases, the incidence of only 35 adverse events from a variety of products containing Cimicifuga alone or in combination with other ingredients suggests a good tolerability of Cimicifuga preparations.

The Commission E, a German governmental body that reviews the use and safety of herbal products, published a positive monograph on Cimicifuga, supporting that the herb is a safe nonprescription drug for "premenstrual discomfort, dysmenorrhea, or climacteric [menopausal] ailments." ${ }^{47}$ The German Commission E does not identify any drug interactions with Cimicifuga treatment, and there are no known adverse drug interactions between isopropanolic extracts and other active substances. However, adverse events reported to the FDA and WHO Collaborating Center highlight the possibility of interactions between Cimicifuga and other herbal products, thus warranting the use of caution when combining herbal products. One case report further highlights the need for caution and indicates individual variations in adverse responses to herbal combinations. A 45-year-old woman who combined separate bottled products of Cimicifuga, Vitex agnus-castus (Nature's Herbs, American Fork, UT) and evening primrose oil to regulate her menstrual cycle reported nocturnal seizures after 4 months of self-treatment. ${ }^{48}$ The patient reported experiencing three generalized tonic-clonic seizures within 3 months of consuming this combination of herbs. Medical history and workup were negative; however, the patient reported consuming alcohol within 48 hours of each episode. The herbal product was discontinued, and she was prescribed carbamazepine, without any further episodes of seizure. The report notes that the patient's sister used the same self-treatment regimen for 1 to 2 years without incidence of side effects.

Despite early suggestions of the safety of Cimicifuga in pregnant women, recent reports discourage the use of Cimicifuga during pregnancy and lactation because possible effects on the fetus have not been adequately studied. ${ }^{49}$ As such, the American Herbal Products Association's Botanical Safety Handbook ${ }^{50}$ suggests that Cimicifuga not be taken during pregnancy or while nursing. Contraindications for use of Cimicifuga during pregnancy may stem from a report of a mother who gave birth after a combination of Cimicifuga and blue cohosh (Caulophyllum thalictroides) was used to induce labor; the child was born without spontaneous breathing and subsequently suffered brain hypoxia. ${ }^{51}$ The contribution of Cimicifuga in this case is improbable, as blue cohosh has been implicated in a similar case report in which an infant suffered an anterolateral myocardial infarction, possibly related to an overdose. In this case, the mother was taking blue cohosh at twice the recommended dose for 3 weeks during the third trimester of pregnancy. ${ }^{52}$ Unlike black cohosh, there is little question that blue cohosh contains some potentially harmful constituents; the plant is featured in standard textbooks on North American poisonous plants. Although there is little scientific data to support the claim, Cimicifuga is not suggested for use in nursing mothers based on the possible maternal transfer of 
TABLE 3. Post marketing studies of Cimicifuga safety in menopause treatment

\begin{tabular}{|c|c|c|c|c|}
\hline Reference & $\begin{array}{c}\text { Study parameters } \\
\text { (subjects exposed } \\
\text { to extract) }\end{array}$ & Cimicifuga formulation & $\begin{array}{c}\text { Treatment } \\
\text { duration }\end{array}$ & Safety-related outcomes \\
\hline $\begin{array}{l}\text { Nesselhut and Liske, } \\
1999^{53}\end{array}$ & 40 menopausal women & $\begin{array}{l}\text { Isopropanolic extract } \\
\text { (Remifemin tablets) }\end{array}$ & 12-week study & $\begin{array}{l}\text { No reported adverse events; no evidence of } \\
\text { estrogenic activity of extract }\end{array}$ \\
\hline
\end{tabular}

Cimicifuga during breast-feeding and on its possible action, including stomach upset and colic, in breast-fed infants. ${ }^{49}$ As such, the WHO monograph on C. racemosa cites pregnancy and lactation as contraindications. ${ }^{46}$

\section{Postmarketing surveillance}

Postmarketing studies support the safety of Cimicifuga extracts (Table 3 ). In the largest postmarketing surveillance study of Cimicifuga solution (ethanolic extract; Remifemin), 629 menopausal women were treated with the Cimicifuga extract for 8 weeks. In this multicenter, open study, only $7 \%$ of the patients developed mild, transitory side effects, predominantly gastrointestinal in nature, none of which required discontinuation of therapy. ${ }^{24}$

A postmarketing surveillance study of isopropanolic Cimicifuga tablets (136 mg drug daily for 3 months) administered to 40 postmenopausal women with menopausal complaints and an endometrial status typical for menopause evaluated the safety of this extract over a 3 -month period. ${ }^{53}$ Of the 28 patients who completed the study (12 did not return to the control examination without stating a reason), the isopropanolic extract did not significantly affect vaginal cell status or reproductive hormones [luteinizing hormone (LH), folliclestimulating hormone ( $\mathrm{FSH})$, estradiol $\left(\mathrm{E}_{2}\right)$, and prolactin] as compared with baseline. Likewise, there was no increase in endometrial thickness in comparison to baseline. In the absence of a positive control, the significance of this finding is unclear. However, based on the lack of adverse events in this 3-month study, there is preliminary evidence supporting the safety of the isopropanolic extract (Remifemin).

The postmarketing experience of Cimicifuga is reflected in the German Commission E monograph as well as in the World Health Organization monograph on Cimicifuga. ${ }^{54}$

\section{Preclinical safety}

Several in vitro and in vivo preclinical studies have been conducted to investigate the effects of Cimicifuga extracts (Tables 4 and 5) on a variety of tissues.
To examine the cytotoxic and mutagenic effects of Cimicifuga extracts, the well-established in vitro screening method developed by Ames ${ }^{55}$ and Ames et $\mathrm{al}^{56,57}$ was used. The Ames test uses a salmonella/microsome assay to detect mutations caused by chemical agents with a reasonable level of reliability. The Ames toxicology study conducted by Schaper \& Brümmer (unpublished internal research, 1990) found no evidence of genetic mutation caused by isopropanolic Cimicifuga extract (Remifemin) at doses ranging from 0.32 to $1000 \mu \mathrm{g} / \mathrm{plate}$. This study demonstrates that the isopropanolic extract does not have a dose-dependent mutagenic effect, nor does it induce biologically relevant increases in mutation rates as compared with the negative (solvent) and positive controls (known mutagenic agents).

Other study groups have validated the lack of mutagenic effects of Cimicifuga. Hemmi and colleagues ${ }^{58}$ tested the effect of Cimicifuga (formulation unspecified) on the uptake of labeled thymidine into phytohemagglutinin-stimulated lymphocytes and mouse lymphosarcoma L-5178 cells and demonstrated that Cimicifuga selectively inhibits the uptake of uridine, adenosine, and thymidine without inhibiting mitosis or DNA synthesis.

A long-term (26 weeks) in vivo study of isopropanolic Cimicifuga (Korn, Schaper \& Brümmer, internal research, 1991) was conducted to determine the toxicity of this extract on various tissues and physiologic systems. This study evaluated the effects of an orally administered Remifemin granulate, which contains the active Cimicifuga constituents, to female Wistar rats for 26 weeks in daily doses of 250,1800 , or 5,000 $\mathrm{mg} / \mathrm{kg}$ body weight, thus reflecting a safety factor up to 740 -fold in comparison to the recommended therapeutic dose. The treated animals were compared with animals treated with $4,982 \mathrm{mg} / \mathrm{kg}$ of the Remifemin additive, a control that mimics the vehicle of the test substance. After an 8-week recovery period, the experimental animals were evaluated on a series of clinical parameters and laboratory measures (Korn, Schaper \& Brümmer, internal research, 1991). 
TABLE 4. In vitro studies highlighting Cimicifuga safety

\begin{tabular}{|c|c|c|c|}
\hline Reference & Study parameters & $\begin{array}{l}\text { Cimicifuga } \\
\text { formulation }\end{array}$ & Safety-related outcomes due to Cimicifuga \\
\hline Hemmi et al, $1979^{58}$ & $\begin{array}{l}\text { Phytohemagglutinin-stimulated lymphocytes } \\
\text { and mouse lymphosarcoma L-5178 cells }\end{array}$ & $\begin{array}{l}\text { Unique extract } \\
\text { formulations } \\
\text { not specified }\end{array}$ & $\begin{array}{l}\text { No cytotoxic or inhibitory effects on cell growth; } \\
\text { no inhibitory effect on DNA synthesis }\end{array}$ \\
\hline $\begin{array}{l}\text { Schaper \& Brümmer, } \\
\text { internal report } \\
\text { (1990) }\end{array}$ & $\begin{array}{l}\text { Histidine auxotrophlic mutants of Salmonella } \\
\text { typhimurium }\end{array}$ & $\begin{array}{l}\text { Isopropanolic } \\
\text { extract }\end{array}$ & $\begin{array}{l}\text { No genetic mutation; no dose-dependent doubling } \\
\text { or biologically relevant increase in mutations }\end{array}$ \\
\hline $\begin{array}{l}\text { Nesselhut et al, } \\
1993^{66}\end{array}$ & Mamma carcinoma cell line MDA MB 435S & $\begin{array}{l}\text { Isopropanolic } \\
\text { extract }\end{array}$ & No growth-stimulating effects \\
\hline $\begin{array}{l}\text { Dixon-Shanies and } \\
\text { Shaikh, } 1999^{68}\end{array}$ & $\begin{array}{l}\mathrm{T}-47 \mathrm{D} \text { and MCF-7 cells (estrogen receptor- } \\
\text { positive cell line) }\end{array}$ & $\begin{array}{r}\text { Ethanolic } \\
\text { extract }\end{array}$ & No growth-stimulating effects \\
\hline Liu et al, $2001^{70}$ & Various in vitro assays & $\begin{array}{l}\text { Methanolic } \\
\text { extract }\end{array}$ & $\begin{array}{l}\text { Lack of estrogen receptor binding and estrogenic } \\
\text { bioactivity }\end{array}$ \\
\hline Zierau et al, $2002^{71}$ & $\begin{array}{l}\text { MCF-7 cells (estrogen receptor-positive } \\
\text { cell line); MVLN cells (estrogen- } \\
\text { inducible cells) }\end{array}$ & $\begin{array}{l}\text { Ethanolic extract } \\
\text { and isopropanolic } \\
\text { extract }\end{array}$ & $\begin{array}{l}\text { Lack of estrogenic effect on cell proliferation or } \\
\text { gene expression }\end{array}$ \\
\hline $\begin{array}{l}\text { Bodinet and } \\
\text { Freudenstein, } 2002^{69}\end{array}$ & $\begin{array}{l}\text { MCF-7 cells (estrogen receptor-positive } \\
\text { cell line) }\end{array}$ & $\begin{array}{l}\text { Isopropanolic } \\
\text { extract }\end{array}$ & Inhibition of cell proliferation \\
\hline Löhning et al, $2000^{\mathrm{a}, \mathrm{b}}$ & $\begin{array}{l}\text { MCF-7 cells (estrogen receptor-positive } \\
\text { cell line) }\end{array}$ & $\begin{array}{r}\text { Ethanolic } \\
\text { extract }\end{array}$ & Low concentrations induced estrogenic effects \\
\hline $\begin{array}{l}\text { Jarry et al, } 1985 \\
1999^{64,65, b}\end{array}$ & Estrogen receptor assay & $\begin{array}{r}\text { Ethanolic } \\
\text { extract }\end{array}$ & $\begin{array}{l}\text { Estrogen receptor binding causing activation of } \\
\text { the transcription of estrogen-regulated genes }\end{array}$ \\
\hline
\end{tabular}

Animals in both the control and isopropanolic extract dose groups appeared to be healthy, with normal motor and sensory activity and body weight development throughout the study period. Reflex, ophthalmoscopic, and auditory examinations did not reveal any adverse findings related to the administration of the test article (Korn, Schaper \& Brümmer, internal research, 1991). Three animals (two in the control group and one in the extract treatment group) died or were in moribund condition throughout the treatment period as a result of accidental (intratracheal) administration. Animals in the extract test group were found to consume slightly more food than the control animals, a finding that may represent a pharmacodynamic effect of the test article. Histopathological examinations of the test animals, however, were unremarkable and noted no estrogen-like morphological changes in organs or tissues after 6 months of treatment. Relative liver weights, however, were slightly increased in the animals treated with the high dose of extract, and significant changes in the heart and ovary weights of the high-dose group were also noted. These observed values returned to normal after 8 weeks of recovery. Clinical chemistry analyses revealed no treatment-related changes at any point during the investigation, and urinalysis did not reveal any notable treatment-related changes. Animals in both the treatment and control groups showed augmented immune reactions; however, there was no statistical significance between such responses (Korn, Schaper \& Brümmer, internal research,1991).

Korn (Schaper \& Brümmer, internal research, 1991) concludes that the slight changes in body weights and food consumption are not toxic effects and that the lack of adverse effects at doses at or below $1,800 \mathrm{mg} / \mathrm{kg}$ body weight over the 6-month period supports the safety of the isopropanolic Cimicifuga extract. Toxicity studies of this type and duration, which provide important predicting potential in determining long-term safety in humans, ${ }^{59}$ support the use of Cimicifuga preparations beyond 6 months.

To fully evaluate the herb's clinical action for menopause treatment, it is important to examine its effect on estrogen-sensitive organs. An early animal study of Cimicifuga preparations on the uterus of mice ${ }^{60}$ suggests that the herb does not adversely affect this organ. Likewise, a study on the uterine growth of immature mice and proliferation of the vaginal epithelium of ovariectomized rats ${ }^{61}$ supports the notion that Cimicifuga extracts do not exert estrogenic effects. In this study, a large dose of ethanolic Cimicifuga $(600 \mathrm{mg} / \mathrm{kg})$ 
TABLE 5. In vivo studies highlighting Cimicifuga safety

\begin{tabular}{|c|c|c|c|c|}
\hline Reference & Study parameters & $\begin{array}{l}\text { Treatment } \\
\text { duration }\end{array}$ & $\begin{array}{l}\text { Cimicifuga } \\
\text { formulation }\end{array}$ & Safety-related outcomes due to Cimicifuga \\
\hline $\begin{array}{l}\text { Korn, } 1991 \text { (Schaper } \\
\text { \& Brümmer internal } \\
\text { report) }\end{array}$ & 120 female Wistar rats & $6 \mathrm{mo}$ & $\begin{array}{l}\text { Isopropanolic } \\
\text { extract }\end{array}$ & No evidence of toxicity \\
\hline Siess, $1960^{60}$ & Mice & Not specified & $\begin{array}{r}\text { Ethanolic } \\
\text { extract }\end{array}$ & No activity on uterus \\
\hline $\begin{array}{l}\text { Einer-Jensen et al, } \\
1996^{61}\end{array}$ & $\begin{array}{l}22 \text { immature mice/ovariectomized } \\
\text { rats }\end{array}$ & $3 d$ & $\begin{array}{r}\text { Ethanolic } \\
\text { extract }\end{array}$ & $\begin{array}{l}\text { No vaginotrophic effects; no uterine growth } \\
\text { or vaginal epithelium growth }\end{array}$ \\
\hline $\begin{array}{l}\text { Nisslein and } \\
\quad \text { Freudenstein, } 2000^{a}\end{array}$ & 30 ovariectomized rats & $5 \mathrm{wk}$ & $\begin{array}{l}\text { Isopropanolic } \\
\text { extract }\end{array}$ & $\begin{array}{l}\text { Inhibitory effect on hormone-regulated bone } \\
\text { resorption }\end{array}$ \\
\hline Freudenstein, $2000^{62}$ & $\begin{array}{l}75 \text { ovariectomized Sprague-Dawley } \\
\text { rats with DMBA-induced } \\
\text { mammary gland tumors }\end{array}$ & $5-9$ wk & $\begin{array}{l}\text { Isopropanolic } \\
\text { extract }\end{array}$ & $\begin{array}{l}\text { No effect on prolactin, FSH, and LH levels } \\
\text { No stimulation of mammary tumor growth } \\
\text { No effect of estrogen-sensitive organs }\end{array}$ \\
\hline $\begin{array}{l}\text { Jarry et al, } 1985, \\
\quad 1999^{64,65 b}\end{array}$ & Ovariectomized rats & $7 \mathrm{~d}$ & $\begin{array}{l}\text { Ethanolic/ } \\
\text { methanolic } \\
\text { extract }\end{array}$ & $\begin{array}{l}\text { Reduction in LH levels; no increase in uterus } \\
\text { weight }\end{array}$ \\
\hline $\begin{array}{l}\text { Jarry and Harnischfeger, } \\
1985^{63 b}\end{array}$ & Ovariectomized rats & $3-14 d$ & $\begin{array}{l}\text { Methanolic } \\
\text { extract }\end{array}$ & $\begin{array}{l}\text { Reduction in LH levels; no change in FSH or } \\
\text { prolactin levels }\end{array}$ \\
\hline
\end{tabular}

LH, luteinizing hormone; FSH, follicle-stimulating hormone; DMBA, 12-dimethylbenz[a]anthracene.

${ }^{a}$ Nisslein T, Freudenstein J. Effects of black cohosh on urinary bone markers and femoral density in an OVX-rat model. Presented at: World Congress on Osteoporosis; June 15-18, 2000; Chicago, Illinois.

${ }^{b}$ Data are contradictory of lack of estrogenic effect of Cimicifuga.

administered orally or subcutaneously did not exert vaginotrophic effects on ovariectomized rats or uterotrophic effects on immature mice.

Similarly, a recent study ${ }^{62}$ of ovariectomized SpragueDawley rats with 7,12-dimethylbenz $[\alpha]$ anthraceneinduced mammary gland tumors shows that, unlike estrogen, Cimicifuga extract - in doses comparable to 1, 10 , or 100 times the human therapeutic dosage - fails to induce mammary tumor development. The study investigators also noted a lack of estrogen-agonist effects on plasma hormone levels (prolactin, FSH, LH), estrogen-sensitive organ weights, and uterine tissue.

In contrast to the studies reviewed above, data from two studies of ovariectomized rats published in 1985 suggest that Cimicifuga causes a selective reduction of LH. ${ }^{63-65}$ Findings suggestive of an estrogenic effect of Cimicifuga may be due to differences in study extraction techniques, extract preparation (ie, isopropanolic, ethanolic, or methanolic), active plant ingredients obtained, cell culture media, and experimental conditions or procedures. It should be noted that the same research team performed both of these studies and that more recent research has not been able to duplicate these results.

Studies using estrogen or progesterone receptorpositive human breast cancer cell lines MCF-7, MDAMB-435S, and T-47D ${ }^{66-69}$ and various in vitro assays ${ }^{70}$ demonstrate that Cimicifuga extracts do not induce estrogenic effects on breast tissue or mammary tumors. In fact, these studies show a consistent inhibitory effect of the isopropanolic Cimicifuga extract on estrogen receptor-positive cancer cells. Cimicifuga extract $\left(10^{-3}-10^{-5}\right.$ dilutions) has been shown to significantly inhibit MCF-7 cell proliferation in estrogen-deprived conditions under test conditions in which estrogen treatment induces proliferation. ${ }^{69}$ Bodinet and Freudenstein ${ }^{69}$ have shown that, in the presence of estrogen, isopropanolic Cimicifuga extract inhibits estrogen-induced proliferation of estrogen receptor-positive cells. In addition, Cimicifuga was found to enhance the inhibitory effect of tamoxifen, a common breast cancer treatment drug, on estrogen receptor-positive cells.

Estrogenic and antiestrogenic activity of ethanolic and isopropanolic extracts of Cimicifuga on proliferation of MCF-7 cells and gene expression were recently tested by Zierau et al. ${ }^{71}$ Estrogenic properties could not be detected in proliferation assays, in gene expression using an $\mathrm{E}_{2}$-inducible yeast assay, or in assays with estrogen-inducible MVLN cells. In fact, in all three experimental systems, C. racemosa antagonized $\mathrm{E}_{2}-$ induced activities. Those investigators concluded that extracts of $C$. racemosa contain compounds that exert antiestrogenic activity. The replication of data by mul- 
tiple teams reassures that Cimicifuga does not induce breast cancer cell proliferation.

\section{Clinical safety}

\section{Clinical Evaluations}

An evaluation of the total number of treated patients, adverse events, tolerability measures, and discontinuation rates reported in clinical trials was conducted to assess the tolerability of Cimicifuga extracts (Table 6). Of the clinical studies reviewed, a total of 2,140 women were treated with Cimicifuga, in doses ranging from 20 to 40 drops of ethanolic extract two times a day (corresponding to $48-140 \mathrm{mg}$ crude drug) to 2 to 4 tablets (corresponding to 39-140 mg crude drug) isopropanolic extract per day for a period of 8 to 52 weeks. During the course of these clinical trials and observational studies, $5.4 \%$ of patients reported adverse events, $97 \%$ of which were minor and did not result in discontinuation of therapy. Of the three severe adverse events reported (one case of thrombophlebitis, in a patient suffering from varicosis; ${ }^{29}$ one case of hysterectomy, recorded as an adverse event in a breast cancer survivor concurrently taking tamoxifen; ${ }^{72}$ and one case of breast cancer recurrence, also in a breast cancer survivor concurrently taking tamoxifen ${ }^{72}$ ), the clinical investigators were unable to ascribe causation to the Cimicifuga extract.

A series of observational studies of Cimicifuga extracts in 1,465 women presenting with menopausal complaints, PMS, or other menstrual or hormonal disorders did not report any adverse effects related to treatment with isopropanolic or ethanolic Cimicifuga extract. ${ }^{73-82}$ Another observational study of 41 patients treated with placebo followed by isopropanolic Cimicifuga extract reported a 7\% incidence of stomach discomfort. ${ }^{83}$ This study also suggests that Cimicifuga may exert a sedative effect; however, the adverse nature of this effect was not specified. In light of these data, the German Commission E monograph reports occasional gastric discomfort as the only noted treatment side effect.

Additional insight into incidence of gastrointestinal discomfort after Cimicifuga treatment is provided by the results of a 12 -week open study. ${ }^{26}$ In this study, 4 of the 50 women treated with 40 drops of an ethanolic Cimicifuga extract two times a day reported mild gastrointestinal disturbances. Similarly, gastric discomfort resulting in treatment withdrawal was reported in $8 \%$ of menopausal women treated with a Cimicifuga preparation (20 mg daily). ${ }^{84}$ However, in the absence of a placebo arm, it is difficult to assess the actual level of in- gredient-induced gastrointestinal adverse events, as such events are commonly reported.

The incidence of other adverse events is noted in several other clinical trials. In an open, uncontrolled study of an ethanolic Cimicifuga extract (48-140 mg drug per day), Daiber ${ }^{25}$ reported two adverse events (one patient reported dry skin and another experienced hair loss). In a similar study, no adverse events or incompatibility reactions from treatment were reported; however, one patient discontinued treatment because of a lack of efficacy on psychological symptoms. ${ }^{27}$ Similarly, a 6-month open trial of an isopropanolic Cimicifuga extract (two tablets twice per day) reported no dropouts or side effects from Cimicifuga treatment in 50 menopausal women previously treated with HRT. ${ }^{28}$

Controlled, double-blinded studies provide additional safety data for Cimicifuga. In a 12-week study, women between the ages of 45 and 58 years were treated with $0.625 \mathrm{mg}$ of conjugated estrogens per day $(n=30)$, isopropanolic Cimicifuga extract per day (two Remifemin tablets twice daily; $n=26)$, or placebo $(n=$ 20). ${ }^{29}$ Of patients treated with the Cimicifuga extract, one patient, who was suffering from varicosis, discontinued therapy because of the aggravation of thrombophlebitis, a state that excluded her from continuing based on the study exclusion criteria. Twelve minor side effects were reported in the Cimicifuga treatment group; however, they did not lead to discontinuation of treatment. Reported side effects included "weight problems," mastodynia, heavy legs, "pepped up" feeling, headaches, and an increase of menopausal complaints that existed before treatment.

Recent studies of various Cimicifuga extracts also suggest a low incidence of adverse events. In a study of 100 premenopausal, perimenopausal, and postmenopausal women treated with an isopropanolic Cimicifuga extract (Remifemin; two tablets per day) for sweating and hot flashes, sleep disorders, depression, and irritation, the only reported adverse event was exanthema facialis without irritation (M. Todorova, unpublished data, 2001). In a study of 34 women treated with Cimicifuga extracts (4 mg triterpene glycosides daily for 6 months) for relief of menopausal symptoms, no side effects were observed; however, 4 patients discontinued therapy in favor of HRT. ${ }^{85}$

In a recent randomized clinical trial of 85 breast cancer survivors ( 59 of whom were concurrently receiving tamoxifen treatment) who were randomly assigned to isopropanolic Cimicifuga extract (20-mg tablet twice daily; $n=42)$ or placebo $(n=43)$ treatment groups, ${ }^{72}$ eight minor adverse events (six in the Cimicifuga/tamoxifen group and two in the Cimicifuga/no tamoxifen 


\section{T. LOW DOG ET AL}

TABLE 6. Clinical studies highlighting Cimicifuga safety in menopause treatment

\begin{tabular}{|c|c|c|c|c|}
\hline Reference & $\begin{array}{c}\text { Study parameters } \\
\text { (subjects exposed to extract) }\end{array}$ & Cimicifuga formulation & $\begin{array}{l}\text { Treatment } \\
\text { duration }\end{array}$ & Safety-related outcomes \\
\hline Schotten, $1958^{73}$ & $\begin{array}{l}22 \text { women with menopausal complaints, } \\
\text { PMS or pregnancy problems }\end{array}$ & $\begin{array}{l}\text { Ethanolic extract } \\
\quad \text { (Remifemin solution) }\end{array}$ & Up to 6 mo & Adverse events were not observed \\
\hline Földes, $1959^{83}$ & 41 menopausal women & $\begin{array}{l}\text { Isopropanolic extract } \\
\text { (Remifemin tablets) }\end{array}$ & $\begin{array}{c}\text { No data on } \\
\text { duration } \\
\text { available }\end{array}$ & $\begin{array}{l}3 \text { patients reported gastrointestinal } \\
\text { disturbances; sedative effect was } \\
\text { noted in some patients }\end{array}$ \\
\hline Stefan, $1959^{75}$ & $\begin{array}{l}46 \text { menopausal women; } 34 \text { girls with } \\
\text { juvenile menstrual disorders; } \\
12 \text { women with general menstrual } \\
\text { disorders; } 2 \text { pregnant women }\end{array}$ & $\begin{array}{l}\text { Isopropanolic extract } \\
\text { (Remifemin tablets) } \\
\text { or ethanolic extract } \\
\text { (Remifemin solution) }\end{array}$ & $\begin{array}{l}\text { No data on } \\
\text { duration } \\
\text { available }\end{array}$ & Adverse events were not observed \\
\hline Stiehler, $1959^{74}$ & $\begin{array}{l}18 \text { menopausal women; and } 53 \text { girls } \\
\text { with amenorrhea and juvenile } \\
\text { menstrual disorders }\end{array}$ & $\begin{array}{l}\text { Isopropanolic extract } \\
\text { (Remifemin tablets) } \\
\text { or ethanolic extract } \\
\text { (Remifemin solution) }\end{array}$ & $\begin{array}{l}\text { No data on } \\
\text { duration } \\
\text { available }\end{array}$ & Adverse events were not observed \\
\hline Brücker, $1960^{76}$ & $\begin{array}{l}517 \text { women with dysmenorrhea and } \\
\text { menopausal complaints }\end{array}$ & $\begin{array}{l}\text { Isopropanolic extract } \\
\text { (Remifemin tablets) } \\
\text { or ethanolic extract } \\
\text { (Remifemin solution) }\end{array}$ & $\begin{array}{c}\text { No data on } \\
\text { duration } \\
\text { available }\end{array}$ & Adverse events were not observed \\
\hline Heizer, $1960^{77}$ & $\begin{array}{l}66 \text { menopausal women; } \\
23 \text { hysterectomized } \\
\text { or ovariectomized } \\
\text { women; } 21 \text { young } \\
\text { women with } \\
\text { amenorrhea, } \\
\text { oligomenorrhea, or } \\
\text { dysmenorrhea }\end{array}$ & $\begin{array}{l}\text { Isopropanolic extract } \\
\text { (Remifemin tablets) } \\
\text { or Ethanolic extract } \\
\text { (Remifemin solution) }\end{array}$ & $2-18 \mathrm{mo}$ & Adverse events were not observed \\
\hline $\begin{array}{l}\text { Starfinger, } \\
\quad 1960^{78}\end{array}$ & 105 menopausal women & $\begin{array}{l}\text { Ethanolic extract } \\
\quad \text { (Remifemin solution) }\end{array}$ & $\begin{array}{l}\text { No data on duration } \\
\text { available }\end{array}$ & Adverse events were not observed \\
\hline Görlich, $1962^{79}$ & $\begin{array}{l}235 \text { women with } \\
\text { hormone-related } \\
\text { conditions, including } \\
\text { amenorrhea, } \\
\text { polymenorrhea, juvenile } \\
\text { menstrual disorders, } \\
\text { PMS, menopausal } \\
\text { complaints, or } \\
\text { pregnancy }\end{array}$ & $\begin{array}{l}\text { Isopropanolic extract } \\
\text { (Remifemin tablets) } \\
\text { or Ethanolic extract } \\
\text { (Remifemin solution) }\end{array}$ & Up to $1 \mathrm{y}$ & Adverse events were not observed \\
\hline $\begin{array}{l}\text { Kesselkaul, } \\
1957^{80}\end{array}$ & 62 menopausal women & $\begin{array}{l}\text { Ethanolic extract } \\
\text { (Remifemin solution) }\end{array}$ & $\begin{array}{l}\text { No data on duration } \\
\text { available }\end{array}$ & Adverse events were not observed \\
\hline $\begin{array}{l}\text { Langfritz, } \\
1962^{81}\end{array}$ & $\begin{array}{l}73 \text { patients with juvenile } \\
\text { menstrual disorders }\end{array}$ & $\begin{array}{l}\text { Ethanolic extract } \\
\quad \text { (Remifemin solution) }\end{array}$ & $3-12 \mathrm{mo}$ & Adverse events were not observed \\
\hline $\begin{array}{l}\text { Schildge, } \\
1964^{82}\end{array}$ & 135 patients with PMS & $\begin{array}{l}\text { Ethanolic extract } \\
\quad \text { (Remifemin solution) }\end{array}$ & $3-6 \mathrm{mo}$ & Adverse events were not observed \\
\hline Daiber, $1983^{25}$ & 36 menopausal women & $\begin{array}{l}\text { Ethanolic extract } \\
\text { (Remifemin solution) }\end{array}$ & 12-wk open study & No adverse events reported \\
\hline Vorberg, $1984^{26}$ & 50 menopausal women & $\begin{array}{l}\text { Ethanolic extract } \\
\text { (Remifemin solution) }\end{array}$ & 12-wk open study & 4 mild gastrointestinal disturbances \\
\hline $\begin{array}{l}\text { Warnecke, } \\
1985^{27}\end{array}$ & 19 menopausal women & $\begin{array}{l}\text { Ethanolic extract } \\
\quad \text { (Remifemin solution) }\end{array}$ & 12-wk open study & No adverse events reported \\
\hline Pethö, $1987^{28}$ & 50 menopausal women & $\begin{array}{l}\text { Isopropanolic extract } \\
\text { (Remifemin tablets) }\end{array}$ & 24-wk open study & No adverse events reported \\
\hline Stoll, $1987^{29}$ & 26 menopausal women & $\begin{array}{l}\text { Isopropanolic extract } \\
\text { (Remifemin tablets) }\end{array}$ & $\begin{array}{l}\text { 12-wk double-blind } \\
\text { study }\end{array}$ & $\begin{array}{l}12 \text { minor side effects reported } \\
1 \text { patient with varicosis developed } \\
\text { thrombophebitis }\end{array}$ \\
\hline Mielnik, $1996^{85}$ & 34 menopausal women & Not specified & $24 \mathrm{wk}$ & No side effects reported \\
\hline
\end{tabular}


TABLE 6. Continued

\begin{tabular}{|c|c|c|c|c|}
\hline $\begin{array}{l}\text { Jacobson et al, } \\
2001^{72}\end{array}$ & $\begin{array}{l}85 \text { breast cancer patients; } \\
59 \text { concurrently taking } \\
\text { tamoxifen }\end{array}$ & Isopropanolic extract & $\begin{array}{l}\text { 8-wk randomized } \\
\text { study }\end{array}$ & $\begin{array}{l}2 \text { serious adverse events in the Cimicifuga/ } \\
\text { tamoxifen group; } 6 \text { minor adverse events } \\
\text { in the Cimicifugal/tamoxifen group; } \\
2 \text { minor adverse events in the Cimicifuga } \\
\text { group; no adverse events related to } \\
\text { Cimicifuga treatment }\end{array}$ \\
\hline $\begin{array}{l}\text { Todorova, } \\
\text { unpublished } \\
\text { data (2001) }\end{array}$ & $\begin{array}{l}100 \text { ( } 23 \text { with hysterectomy) } \\
\text { menopausal women }\end{array}$ & $\begin{array}{l}\text { Isopropanolic extract } \\
\text { (Remifemin tablets) }\end{array}$ & $12-52 \mathrm{wk}$ & $\begin{array}{l}\text { One report of exanthema facialis without } \\
\text { irritation }\end{array}$ \\
\hline $\begin{array}{l}\text { Liske et al, } \\
\quad 2002^{31}\end{array}$ & $\begin{array}{l}152 \text { perimenopausal and } \\
\text { postmenopausal women }\end{array}$ & $\begin{array}{l}\text { Isopropanolic extract } \\
\text { (Remifemin tablets) }\end{array}$ & $\begin{array}{l}\text { 24-wk controlled, } \\
\text { randomized, double- } \\
\text { parallel group study }\end{array}$ & $\begin{array}{l}5 \text { gastrointestinal disturbances; } 5 \text { CNS } \\
\text { adverse effects; } 5 \text { adverse effects on } \\
\text { breasts and/or genitals; } 4 \text { nonspecified } \\
\text { adverse events; all events were mild to } \\
\text { moderate in severity }\end{array}$ \\
\hline
\end{tabular}

PMS, premenstrual syndrome; CNS, central nervous system.

group) were reported. Study investigators, however, concluded that none of the reported events were Cimicifuga treatment related. Similarly, two serious adverse events (both in the Cimicifuga/tamoxifen group) were reported but not deemed to be Cimicifuga related.

\section{Dose-related safety}

Although reports of adverse events associated with Remifemin and other Cimicifuga extract therapies have been few in clinical investigations, there have been reports of untoward reactions to large (unspecified) doses of Cimicifuga. These include hypotension, general relaxation, vertigo, tremors, headaches, giddiness, and occasional vomiting. ${ }^{86}$ Many of these reported adverse reactions are from the early reports of Cimicifuga use dating back to the mid-19th century. ${ }^{13}$ As such, it is unlikely that similar reactions occur with the appropriate use of the currently available, clinically tested Cimicifuga extracts. Although there are a number of Cimicifuga doses currently used without the occurrence of side effects, caution is warranted when administering any dietary supplements in quantities exceeding the recommended, clinically tested daily dose.

To confirm the safety of the commercially accepted doses of isopropanolic Cimicifuga extract, Liske and colleagues ${ }^{31}$ conducted a 24 -week controlled, randomized, double-blinded parallel-group study of two doses of the isopropanolic Cimicifuga preparation [Remifemin (standard dose: $39.0 \mathrm{mg} /$ day; high dose: 127.3 $\mathrm{mg} /$ day)] in 152 perimenopausal and postmenopausal women. Both the standard- and high-dose groups reported "good" and "very good" tolerability ratings (standard: $94.7 \%$ at 12 weeks and $100 \%$ at 24 weeks; high: $82 \%$ at 12 weeks and $100 \%$ at 24 weeks), and adverse-event reports for both dose groups were comparable. The 19 reported adverse events were mild or moderate and can be classified as gastrointestinal effects ( 1 report in the standard-dose group; 4 reports in the high-dose group); central nervous system effects (1 report in the standard-dose group; 4 reports in the highdose group); effects on the breasts or genitals (3 reports in the standard-dose group; 2 reports in the high-dose group); and other nonspecified effects ( 2 reports in the standard-dose group; 2 reports in the high-dose group). Whereas one patient reported metrorrhagia determined to be caused by an inactive endometrium, none of the adverse events reported in this study can be directly attributed to intake of the Cimicifuga extract. ${ }^{31}$

\section{Safety in special populations}

As HRT is contraindicated in women with estrogensensitive cancers of the breast and uterus, the possible tumor-promoting activity of alternative estrogen-like therapies requires special evaluation, particularly in relation to the clinical application of Cimicifuga extracts. Several clinical studies as well as human clinical trials (reviewed earlier in this section) have evaluated the potential of Cimicifuga extracts to induce proliferation of estrogen receptor-positive cells or changes in estrogendependent hormones (Table 7).

Estrogen naturally decreases during menopause, thus initiating an estrogen-dependent negativefeedback cycle that causes LH and FSH levels to increase ${ }^{87}$ Therefore, estrogenic activity would likely result in decreased levels of LH and FSH. A clinical trial of perimenopausal and postmenopausal women that investigated the effects of Cimicifuga on the female reproductive system over a 24 -week period evaluated the physiologic effects of the medicinal herb based on vaginal cytology measures (degree of cell proliferation in the vaginal epithelium, the karyopyknotic index, and the eosinophilic index) and reproductive hormone lev- 
TABLE 7. Clinical studies highlighting Cimicifuga safety in special populations

\begin{tabular}{|c|c|c|c|c|c|}
\hline Reference & Study parameters & Cimicifuga formulation & Treatment duration & $\begin{array}{l}\text { Cimicifuga effects on } \\
\text { hormone levels }\end{array}$ & $\begin{array}{l}\text { Cimicifuga } \text { effects } \\
\text { on cell proliferation }\end{array}$ \\
\hline $\begin{array}{l}\text { Liske et al, } \\
\qquad 2002^{31}\end{array}$ & $\begin{array}{l}152 \text { perimenopausal and } \\
\text { postmenopausal } \\
\text { women }\end{array}$ & $\begin{array}{l}\text { Isopropanolic extract } \\
\text { (Remifemin tablets) }\end{array}$ & $\begin{array}{l}\text { 24-wk controlled, } \\
\text { randomized, double- } \\
\text { parallel group study }\end{array}$ & $\begin{array}{l}\text { No change in LH, FSH, } \\
\text { prolactin, or sex } \\
\text { hormone-binding } \\
\text { globulin levels }\end{array}$ & $\begin{array}{c}\text { No vaginal cell } \\
\text { proliferation }\end{array}$ \\
\hline $\begin{array}{l}\text { Georgiev and } \\
\text { Tordanova, } \\
1997^{88}\end{array}$ & 50 menopausal women & Isopropanolic extract & $12 \mathrm{wk}$ & Not reported & $\begin{array}{l}\text { No change in } \\
\text { endometrial } \\
\text { thickness }\end{array}$ \\
\hline $\begin{array}{l}\text { Lehmann- } \\
\text { Willenbrock } \\
\text { and Riedel, } \\
1998^{30}\end{array}$ & $\begin{array}{l}\text { Hysterectomized } \\
\text { women }\end{array}$ & $\begin{array}{l}\text { Isopropanolic extract } \\
\text { (Remifemin tablets) }\end{array}$ & 24-wk study & $\begin{array}{l}\text { No change in } \\
\text { reproductive } \\
\text { hormone levels }\end{array}$ & Not investigated \\
\hline $\begin{array}{l}\text { Nesselhut and } \\
\text { Liske, } 1999^{53}\end{array}$ & $\begin{array}{l}\text { Postmenopausal } \\
\text { women }\end{array}$ & $\begin{array}{l}\text { Isopropanolic extract } \\
\text { (Remifemin tablets) }\end{array}$ & $12 \mathrm{wk}$ & $\begin{array}{l}\text { No change in } \\
\text { hormone levels }\end{array}$ & $\begin{array}{l}\text { No change in } \\
\text { endometrial } \\
\text { thickness }\end{array}$ \\
\hline $\begin{array}{l}\text { Jacobson et al, } \\
2001^{72}\end{array}$ & $\begin{array}{l}85 \text { breast cancer } \\
\text { patients; } 59 \\
\text { concurrently taking } \\
\text { tamoxifen }\end{array}$ & Isopropanolic extract & $\begin{array}{l}\text { 8-wk randomized } \\
\text { study }\end{array}$ & $\begin{array}{l}\text { No change in LH } \\
\text { and FSH levels }\end{array}$ & $\begin{array}{l}\text { No regrowth of } \\
\text { cancerous breast } \\
\text { tissue }\end{array}$ \\
\hline $\begin{array}{l}\text { Maamari and } \\
\text { Schreiber, } \\
2001^{84}\end{array}$ & $\begin{array}{l}50 \text { menopausal women, } \\
\text { including } 5 \text { breast } \\
\text { cancer survivors }\end{array}$ & Not specified & 24-wk study & Not reported & $\begin{array}{l}\text { No change in } \\
\text { mammography, } \\
\text { pap smear, and } \\
\text { vaginal ultrasound }\end{array}$ \\
\hline $\begin{array}{l}\text { Düker et al, } \\
1991^{89, a}\end{array}$ & 52 menopausal women & Ethanolic extract & 8-wk study & $\begin{array}{l}\text { No reduction in FSH } \\
\text { levels; significant } \\
\text { reduction in LH } \\
\text { levels }\end{array}$ & Not investigated \\
\hline
\end{tabular}

$\mathrm{LH}$, luteinizing hormone; FSH, follicle-stimulating hormone.

${ }^{a}$ Data are contradictory of lack of estrogenic effect of Cimicifuga.

els. ${ }^{31}$ The vaginal cytology measures demonstrated that Cimicifuga did not induce cell proliferation or other adverse effects nor cause significant alterations in $\mathrm{E}_{2}, \mathrm{LH}, \mathrm{FSH}$, prolactin, and sex hormone-binding globulin levels after treatment with the standard (39.0 $\mathrm{mg} /$ day) or high (127.3 mg/day) dose of Cimicifuga. On the basis of vaginal cytology and hormone findings from this clinical study, it appears that the beneficial effects of Cimicifuga extracts on menopausal symptoms are not associated with systemic estrogenagonistic effects. The noted lack of estrogenic effect of Cimicifuga on female reproductive hormones has also been demonstrated in a study of hysterectomized menopausal patients. ${ }^{30}$

The results of Liske et $\mathrm{al}^{31}$ confirm data from Nesselhut and Liske ${ }^{53}$ that support a lack of estrogenic effect of Cimicifuga on the female genital tract. In their study, postmenopausal women treated with an isopropanolic Cimicifuga extract (136 mg crude drug per day) for 3 months showed no change in the endometrial thickness, monitored by transvaginal sonography, or in hormone levels ( $E_{2}, \mathrm{LH}, \mathrm{FSH}$, and prolactin). Similarly, Jacobson et $\mathrm{al}^{72}$ found that Cimicifuga treatment did not significantly alter LH and FSH levels in breast cancer survivors as compared with placebo-treated breast cancer patients, nor did the extract induce cancerous regrowth of breast tissue. Likewise, a study of 50 women, including 5 breast cancer survivors, treated with $20 \mathrm{mg}$ /day of a Cimicifuga extract for relief of hot flashes and night sweats found that mammography, pap smear, and vaginal ultrasound results were comparable to baseline over a 24 -week period. ${ }^{84} \mathrm{~A}$ similar study of 50 women treated with an isopropanolic Cimicifuga extract noted that endometrial thickness was not influenced by the 12 -week treatment. ${ }^{88}$ Although long-term studies are needed, these data suggest that Cimicifuga is safe for women who reject or cannot take HRT. ${ }^{84}$

In contradiction to reports demonstrating an estrogen-antagonistic or nonestrogenic effect of Cimicifuga, some findings have been consistent with an estrogenic mode of action. In an open study of 52 menopausal women treated with Cimicifuga, Düker et al ${ }^{89}$ report that although FSH levels did not decrease in comparison to placebo-treated patients, the Cimicifuga extract significantly reduced LH levels in the treated population. The selective suppression of LH secretion in 
menopausal women treated with Cimicifuga extracts in this study points toward an estrogenic mode of action corresponding with the natural decrease in estrogen, which triggers a feedback cycle causing an increase in LH levels. Similarly, an open, comparative study by Warnecke showed proliferation of the vaginal epithelium, which could be indicative of an estrogenic mechanism of action. ${ }^{27}$ However, absence of some data, including baseline FSH and LH levels, placebo controls, and controls for effective randomization, may limit the interpretability of these studies.

\section{DISCUSSION}

\section{Benefit-risk analysis}

Uncontrolled reports, postmarketing surveillance, and human clinical trials including more than 2,800 patients demonstrate the low incidence of adverse events, particularly reports associated with single-agent Cimicifuga use. Likewise, scientific investigations of the estrogenic activity of isopropanolic extracts of Cimicifuga demonstrate the safety of this therapy for a period of 24 weeks in individuals with a history of estrogen-dependent neoplasms.

The largest postmarketing clinical investigation of Remifemin reports that more than $80 \%$ of the treated patients showed improvement in menopausal symptoms, including hot flashes, sweating, headaches, vertigo, palpitation, tinnitus, nervousness/irritability, and depression. ${ }^{24}$ Similarly, controlled, randomized studies have found that an isopropanolic Cimicifuga extract (Remifemin Menopause) was just as effective as therapies using estrogen or the psychoactive drug diazepam for managing menopausal symptoms over a period of 3 months. ${ }^{27,28,30}$ Although many of these studies have methodological flaws, including lack of a placebocontrolled arm, these data, coupled with the excellent safety record and extremely low incidence of adverse events, suggest a positive benefit-to-risk ratio.

\section{CONCLUSIONS}

Cimicifuga isopropanolic extract has a long history of clinical use and has been used in Europe for almost 50 years to manage menopausal symptoms. Supported by postmarketing experience, clinical trials, and toxicology reviews of up to 6 months in duration and by in vitro and in vivo studies, the favorable safety and toxicity profile of Cimicifuga extracts for use in women with hormonal disorders, including menopause, has been clearly demonstrated. It is noteworthy that the commercially available isopropanolic Cimicifuga formulation (Remifemin) has been widely studied and shown not to induce cytotoxic, mutagenic, carcinogenic, or teratogenic effects at doses much larger than the human therapeutic dose. Thus, Cimicifuga extracts, such as the isopropanolic formulation, appear to be safe for use in women currently experiencing menopausal symptoms.

Because of concerns regarding the safety of treatments used to relieve menopausal symptoms, particularly the potential adverse effects of HRT, the safety of alternative treatments requires intense examination. Although few reports suggest that Cimicifuga may act through an estrogen-like mechanism, there is significant scientific data stemming from various in vitro and in vivo studies that seriously cast doubt upon this hypothesis. Although we recognize that a large, long-term study using rigorous methodology is needed to estimate the size and mechanism of treatment effect, after reviewing all of the data regarding adverse events and toxicology, practitioners should be reassured that Cimicifuga treatment appears to be a safe option for women who wish to take it for relief of menopausal symptoms.

\section{REFERENCES}

1. Lobo RA. Menopause management for the millennium CME. Medical Education Collaborative. Available at: www.medscape. $\mathrm{com} /$ medscape/WomensHealth/ClinicalMgmt/CM.v01/public/index.CM.v01.html. Accessed October 17, 2000.

2. Risks and benefits of estrogen plus progestin in healthy postmenopausal women: principal results from the Women's Health Initiative randomized controlled trial. JAMA 2002;288:321-333.

3. Rodriguez C, Patel AV, Calle EE, Jacob EJ, Thun MJ. Estrogen replacement therapy and ovarian cancer mortality in a large prospective study of US women. JAMA 2001;285:1460-1465.

4. Anonymous. Breast cancer and hormone replacement therapy: collaborative reanalysis of data from 51 epidemiological studies of 52,705 women with breast cancer and 108,411 women without breast cancer. Collaborative Group on Hormonal Factors in Breast Cancer. Lancet 1997;350:1047-1059.

5. Lieberman S. A review of the effectiveness of cimicifuga racemosa (black cohosh) for the symptoms of menopause. J Womens Health 1998;7:525-529.

6. United States Preventive Services Task Force. Postmenopausal hormone replacement therapy for primary prevention of chronic conditions: recommendations and rationale. Ann Intern Med 2002;137: 834-839.

7. Alexander KP, Newby LK, Hellkamp AS, et al. Initiation of hormone replacement therapy after acute myocardial infarction is associated with more cardiac events during follow-up. $\mathrm{J} \mathrm{Am} \mathrm{Coll} \mathrm{Car}$ diol 2001;38:1-7.

8. Taylor M. Nonhormonal alternatives for the menopause syndrome. Infertil Reprod Med Clin North Am 2001;12:669-685.

9. Israel D, Youngkin EQ. Herbal therapies for perimenopausal and menopausal complaints. Pharmacotherapy 1997;17:970-984.

10. Wade C, Kronenberg F, Kelly A, Murphy PA. Hormonemodulating herbs: implications for women's health. J Am Med Wom Assoc 1999;54:181-183.

11. Gleason H, Cronquist A. Manual of Vascular Plants of Northeastern United States and Adjacent Canada. New York, NY: New York Botanical Garden, 1991.

12. Young J. Observations on the remedial powers of the cimicifuga racemosa in the treatment of chorea. Am J Med Sci 1831;9:310-315. 
13. Davis NS. Cimicifuga racemosa: actoea racemosa, black cohosh, polypetalous exogenous, nat. ord., ranunculaceae, sex. syst., polyandria di pentagynia. Trans J Am Med Assoc 1848;1:351-357.

14. Mundy W. Macrotys. Eclectic Med J 1923;83:468-470.

15. Webster H. Cimicifuga racemosa. Eclectic Med J 1901;61:195-198.

16. Scudder J. Macrotys racemosa. Eclectic Med J 1871;31:574-575.

17. Felter H. My medicine case-macrotys. Eclectic Med J 1915;75: 154-155.

18. Felter H. Macrotys. Eclectic Med J 1928;88:284-288.

19. Grieve M. A Modern Herbal: The Medicinal, Culinary, Cosmetic and Economic Properties, Cultivation and Folk-Lore of Herbs, Grasses, Fungi, Shrubs \& Trees with their Modern Scientific Uses. New York: Dover Publications, 1971.

20. Niederkorn J, Versailles O. Macrotys and caulophyllin. Eclectic Med J 1910;70:63-66.

21. McKenna DJ, Jones K, Humphrey S, Hughes K. Black cohosh: efficacy, safety, and use in clinical and preclinical applications. Alternative Ther Health Med 2001;7:93-100.

22. Parrish E. Therapeutical and pharmaceutical notes on Cimicifuga. Eclectic Med J 1861;20:197-200.

23. Scudder J. Macrotys in pregnancy and parturition. Eclectic Med J 1875;35:477-478.

24. Stolze H. An alternative to treat menopausal complaints [in German]. Gyne 1982;1:14-16.

25. Daiber W. Climacteric complaints: success without using hormones! A phytotherapeutic agent lessens hot flushes, sweating, and insomnia [in German].Arztl Prax 1983;65:1946-1947.

26. Vorberg G. Treatment of menopausal complaints [in German]. $Z$ Allgemeinmed 1984;13:626-629.

27. Warnecke G. Influencing menopausal symptoms with a phytotherapeutic agent: successful therapy with cimicifuga mono-extract [in German]. Med Welt 1985;36:871-874.

28. Pethö A. Menopausal complaints: change-over of a hormone treatment to a herbal gynecological remedy practicable? [in German]. Arztl Prax 1987;47:1551-1553.

29. Stoll W. Phytopharmacon influences atrophic vaginal epithelium: double-blind study: Cimicifuga vs estrogenic substances [in German]. Therapeutikon 1987;1:23-31.

30. Lehmann-Willenbrock E, Riedel H. Clinical and endocrinological examinations concerning therapy of climacteric symptoms following hysterectomy with remaining ovaries [in German]. Zentralbl Gynakol 1998;110:611-618.

31. Liske E, Hänggi W, Henneicke-von Zepelin H, Boblitz N, Wüstenberg P, Rahlfs V. Physiologic investigation of a unique extract of black cohosh (Cimicifugae racemosae rhizoma): a 6-month clinical study demonstrates no systemic estrogenic effect. $J$ Womens Health Gender Based Med 2002;11:163-174.

32. Bowles T, Harrison O. Some uses for macrotys. Eclectic Med J 1923;83:429-431.

33. Lloyd J. Cimicifuga. Eclectic Med J 1878;38:118-119.

34. Fisk F. Macrotys. Eclectic Med J 1912;72:333-335.

35. Mahady G. Black cohosh. In: Mahady G, Fong HHS, Farnsworth NR, eds. Botanical Dietary Supplements: Quality, Safety, and Efficacy. Lisse, Netherlands: Swets \& Zeitlinger B.V., 2001:27-34.

36. Cook W. Cimicifuga racemosa: black cohosh, rattleroot, black snakeroot, squawroot, bugbane. In: Cook W, ed. Physiomedical Dispensatory. Cincinnati, OH: Wm. H Cook, 1869.

37. Whitney W. Cimicifuga (macrotys) racemosa. Eclectic Med J 1888; 48:162-164

38. Scudder J. Varieties. Eclectic Med J 1864;24:236-237.

39. Howe A. Cimicifuga and abortion. Eclectic Med J 1885;45:501502.

40. Hutchinson R. The physiological action of Cimicifuga racemosa. Ther Gazette 1887;731-733.

41. Macht $\mathrm{D}$, Cook H. A pharmacological note on Cimicifuga. $J$ Am Pharm Assoc 1932;21:324-330.

42. von Gizycki H. Arzneipflanzen in ihren beziehungen zum weiblichen genitalsystem. versuche an weiben ratten und mäusen mit cimicifuga racemosa. Z Ges Exp Med 1944;113:635-644.
43. Schindler H. Die Inhaltsstoffe von heilpflanzen und prüfungsmethoden für pflanzliche tinkturen. Arzneimittelforschung 1952;2:547549.

44. Food and Drug Administration (FDA). The SN/AEMS Web report: search results for black cohosh. Available at: http://vm.cfsan. gov/cgi-bin?QUERY $=$ black + cohosh $\&$ STYPE $=$ EXACT . Accessed October 18, 2001.

45. Food and Drug Administration (FDA). The SN/AEMS Web report: search results for cimicifuga. Available at: http://vm.cfsan.fda gov/cgi-bin/aems.cgi?QUERY $=$ cimicifuga\&STYPE $=$ EXACT . Accessed October 18, 2001.

46. World Health Organization Collaborating Center. Adverse Reactions to Drugs: Cimicifuga Racemosa, Cimicifuga Racemosa Root, Cimicifuga Racemosa Extract. Welwyn Garden City, UK: ECRI, 2000

47. Blumenthal M, Busse W, Goldberg A, et al. German Commission E Monographs: Therapeutic Monographs on Medicinal Plants for Human Use. Austin, TX: American Botanical Council, 1998.

48. Shuster J. ISMP adverse drug reactions. Hosp Pharm 1996;31: 1553-1554.

49. Brinker F. Herb Contraindications and Drug Interactions, 2nd ed. Sandy, OR: Eclectic Medica, 1998.

50. McGuffin M, Hobbs C, Upton R, Goldberg A. American Herbal Products Association's Botanical Safety Handbook. Boca Raton, FL: CRC Press, 1997.

51. Gunn TR, Wright IM. The use of black and blue cohosh in labour. $N$ Z Med J 1996;109:410-411.

52. Jones TK, Lawson BM. Profound neonatal congestive heart failure caused by maternal consumption of blue cohosh herbal medication. J Pediatr 1998;132:550-552

53. Nesselhut T, Liske E. Pharmacological measures in postmenopausal women with an isopropanolic aqueous extract of cimicifugae racemosae rhimoza [Abstract]. Presented at: 10th Annual Meeting, The North American Menopause Society, 1999, New York.

54. World Health Organization [WHO]. Rhizoma cimicifugae racemosae. Geneva, Switzerland: WHO Publications, 2002. WHO Monographs on Selected Medicinal Plants;2:56-65.

55. Ames BN. Carcinogens are mutagens: their detection and classification. Environ Health Perspect 1973;6:115-118.

56. Ames BN, Lee FD, Durston WE. An improved bacterial test system for the detection and classification of mutagens and carcinogens. Proc Natl Acad Sci U S A 1973;70:782-786.

57. Ames BN, McCann J, Yamasaki E. Methods for detecting carcinogens and mutagens with the Salmonella/mammalian-microsome mutagenicity test. Mutat Res 1975;31:347-364.

58. Hemmi H, Kitame F, Ishida N. Inhibition of sterol and DNA syntheses in phytohemagglutinin-stimulated human lymphocytes by 7 alpha-hydroxycholesterol. Tohoku J Exp Med 1979;145:105-113.

59. Ball SE, Scatina JA, Sisenwine SF, Fisher GL. The application of in vitro models of drug metabolism and toxicity in drug discovery and drug development. Drug Chem Toxicol 1995;18:1-28.

60. Siess V, Seybold G, Einleitung I. Untersuchungen über die wirkung von pulsatilla pratensis, cimicifuga racemosa und aristolochia clematitis auf den östrus infantiler und kastrierter weiblicher mäuse. Arzneimittelforschung 1960;10:514-520.

61. Einer-Jensen N, Zhao J, Andersen KP, Kristoffersen K. Cimicifuga and Melbrosia lack oestrogenic effects in mice and rats. Maturitas 1996;25:149-153.

62. Freundenstein J, Dasenbrock C, Nisslein T. Lack of promotion of estrogen dependent mammary gland tumors in vivo by an isopropanolic black cohosh extract. Third International Congress on Phytomedicine. Phytomedicine 2000;7(Suppl):13.

63. Jarry H, Harnischfeger G. Endocrine effects of constituents of Cimicifuga racemosa. 1. The effect on serum levels of pituitary hormones in ovariectomized rats. Planta Med 1985;46-49.

64. Jarry H, Harnischfeger G, Düker E. The endocrine effects of constituents of cimicifuga racemosa. 2. In vitro binding of constituents to estrogen receptors. Planta Med 1985;316-319.

65. Jarry H, Leonhardt S, Düls C, et al. Organ-specific effects of cimi- 
cifuga racemosa (CR) in brain and uterus. Presented at: 23rd International LOF-Symposium on "Phyto-Oestrogen," January 15, 1999; Ghent, Belgium.

66. Nesselhut T, Schellhase C, Dietrich R, Kuhn W. Studies of mamma carcinoma cells regarding the proliferative potential of herbal medication with estrogenic-like effects [in German]. Arch Gynecol Obstet 1993;254:817-818.

67. Zava DT, Dollbaum CM, Blen M. Estrogen and progestin bioactivity of foods, herbs, and spices. Proc Soc Exp Biol Med 1998;217: 369-378.

68. Dixon-Shanies D, Shaikh N. Growth inhibition of human breast cancer cells by herbs and phytoestrogens. Oncol Rep 1999;6:13831387.

69. Bodinet C, Freudenstein J. Influence of Cimicifuga racemosa on the proliferation of estrogen receptor-positive human breast cancer cells. Breast Cancer Res Treat 2002;76:1-10.

70. Liu J, Burdette JE, Xu H, et al. Evaluation of estrogenic activity of plant extracts for the potential treatment of menopausal symptoms. J Agric Food Chem 2001:49:2472-2479.

71. Zierau O, Bodinet C, Kolba S, Wulf M, Vollmer G. Antiestrogenic activities of cimicifuga racemosa extracts. J Steroid Biochem Mol Biol 2002;801:125-130.

72. Jacobson JS, Troxel AB, Evans J, et al. Randomized trial of black cohosh for the treatment of hot flashes among women with a history of breast cancer. J Clin Oncol 2001;19:2739-2745.

73. Schotten E. Erfahrungen mit dem cimicifuga-präparat Remifemin. Landarzt 1958;34:353-354.

74. Stiehler K. Uber die anwendung eines standardisierten cimicifugaAuszuges in der gynäkologie. Arztl Prax 1959;11:916-917.

75. Stefan H. Ein Beitrag zu den erscheinungsformen und zur therapie hormonal bedingter biopathiesyndrome der Frau. Ringelheimer Biol Umsch 1959;14:149-152.

76. Brücker A. A discussion of the phytotherapy of female hormonal disorders [in German]. Med Welt 1960;44:2331-2333.
77. Heizer H. Kritisches zur cimicifuga-therapie bei hormonalen störungen der Frau. Med Klin 1960;55:232-233.

78. Starfinger $\mathrm{W}$. Therapie mit östrogen-wirksamen pflanzenextrakten Med Heute 1960;9:173-174.

79. Görlich N. Behandlung ovarieller störungen in der allgemeinpraxis. Arztl Prax 1962;14:1742-1743.

80. Kesselkaul O. Uber die behandlung klimakterischer beschwerden mit Remifemin. Med Monatsschr 1957;11:87-88.

81. Langfritz W. Beitrag zur therapie von regeltempoanomalien und deren begleiterscheinungen bei jungen mädchen und jungen frauen. Med Klin 1962;57:1497-1499.

82. Schildge E. Beitrag zur behandlung von prämenstruellen und klimakterischen verstimmungs - und depressionszuständen. Ringelheimer Biologische Umschau 1964;19:18-22.

83. Földes J. The effects of an extract of cimicifuga racemosa. Arztl Forsch 1959;13:623-624.

84. Maamari R and Schreiber A. Cimicifuga racemosa and quality of life. In: The NAMS Program and Abstract Book, 12th Annual Meeting of The North American Menopause Society; October 4-6, 2001; New Orleans, LA. Abstract P-10.

85. Mielnik J. Extract of cimicifuga racemosa in the treatment of neurovegetative symptoms in women in the perimenopausal period. In: Program and abstracts of the 8th International Congress on Menopause; 1996; Sydney, Australia. Abstract P-318.

86. Facts and Comparisons: The Review of Natural Products. St. Louis: JB Lippincott, 1992.

87. Abrams WB, Beers MH, Berkown R. Merck Manual of Geriatrics. Whitehouse Station, NJ: Merck, 2000

88. Georgiev DB, Iordanova E. Phytoestrogens - the alternative approach. Maturitas 1997;27(Suppl):273.

89. Düker EM, Kopanski L, Jarry H, Wuttke W. Effects of extracts from cimicifuga racemosa on gonadotropin release in menopausal women and ovariectomized rats. Planta Med 1991;57:420-424. 